\title{
Renewable rural electrification: Sustainability assessment of mini-hybrid off-grid technological systems in the African context
}

\author{
Alan Colin Brent ${ }^{\mathrm{a}, \mathrm{b}, *}$, David E. Rogers ${ }^{\mathrm{c}}$ \\ ${ }^{a}$ Resource Based Sustainable Development, Natural Resources and the Environment, CSIR, Stellenbosch, South Africa \\ ${ }^{\mathrm{b}}$ Graduate School of Technology Management, University of Pretoria, South Africa \\ ${ }^{\mathrm{c}}$ Energy and Processes, Material Science and Manufacturing, CSIR, Pretoria, South Africa
}

\section{A R T I C L E I N F O}

\section{Article history:}

Received 18 December 2008

Accepted 29 March 2009

Available online $\mathrm{xxx}$

\section{Keywords:}

Sustainability science

Sustainable development

Technology management

Technology assessment

Technology transfer

Sustainability indicators

\begin{abstract}
A B S T R A C T
The investigation summarised in this paper applied a sustainability assessment methodology on a renewable energy technological system in a rural village project that was commissioned by the South African Department of Minerals and Energy. The project comprised of wind, solar and lead-acid battery energy storage technologies that were implemented as a mini-hybrid off-grid electrification system for the village. The sustainability assessment methodology predicts the outcomes of such interventions by way of a learning model using discipline experts in the fields of economics, sociology, ecosystem sustainability, institutional governance, and the physics and chemistry of energy conversion processes. The comparison of the project's outcomes with a South African sustainable development framework shows that the specific village renewable off-grid electrification system is not viable. The main reason is that charges for electricity supply costs in village grids are too high for available subsidies; the economies of scale for renewable energy supply technologies favour national grids. The failure of the integrated system may also be attributable to the complexity of the social-institutional sub-system, which resulted in uncertainty for project planners and system designers, and the lack of resilience of the technological system to demands from the socio-economic and institutional sub-systems. Policy-related recommendations are made accordingly.
\end{abstract}

(c) 2009 Elsevier Ltd. All rights reserved.

\section{Introduction}

The South African governance system is developing national measures of sustainability. For example, the Millennium Development Goals are pursued to reduce widespread poverty by 2015 [1]. The post Kyoto 2012 commitments to low-carbon technologies to mitigate the effects of climate change are based on renewable energies, which are to be supported by a carbon tax [2]. In terms of mitigation, the application of (energy) technological innovation to meet the objectives of sustainable development and the conditions for sustainability has been stressed [3-5]; a model, based on the principles of sustainability science (see Table 1), has been developed that can be used to assess the sustainability of such technologies (see Fig. 1) [5]. The model integrates:

- A life cycle perspective [4] and systems thinking, i.e. systems provide feedback loops and are self-correcting [6].

\footnotetext{
* Corresponding author. Tel.: +27 218882466; fax: +27 218882693

E-mail address: abrent@csir.co.za (A.C. Brent).
}

- Learning methods for the management of information in the paradigm of sustainable development [5].

- Conditions for sustainability to reduce the complexity of systems by clarifying the magnitude of cause and effect on systems, so that priorities can be allocated [5].

- Technology innovation and what is feasible within constraints of time, finances and institutions [3,4].

The model to prioritise assessable sustainability indicators for renewable energy systems initiates with a comprehensive set of sustainable development indicators that are deemed appropriate for the context of integrated renewable energy technological systems under investigation. Only those indicators that are controllable by decision-makers in the context of an integrated technological system, and specifically those that are expected, by the technological sub-system analysts, to be effected through the implementation of the technological sub-system, are considered further (\#1 in Fig. 1).

The remainder of the approach is based on the Kolb learning cycle of experience, reflection, conceptualisation and planning [7]. First, the expertise of the technological sub-system analysts, with the expertise of the sustainability of the economic, environmental, 
Table 1

Specific theories of the emerging field of sustainability science that relate to sustainability performance indicators for technological systems [5].

\begin{tabular}{|c|c|c|}
\hline Theory & In the context of sustainability science & In the context of performance indicators of technologies \\
\hline Trans-disciplinarity & $\begin{array}{l}\text { The result of a coordination of disciplines such as science and laws of nature; technology } \\
\text { and what is achievable; law and politics and what is acceptable to social systems; and } \\
\text { ethics of what is right and wrong beyond the bounds of society. }\end{array}$ & $\begin{array}{l}\text { Where: "successful transformation of technologies into } \\
\text { marketable commodities requires knowledge and skills } \\
\text { from a variety of different specialist fields of science and } \\
\text { engineering". }\end{array}$ \\
\hline Resilience & $\begin{array}{l}\text { A system's ability to bounce back to a reference state after a disturbance and the capacity } \\
\text { to maintain characteristic structures and functions despite the disturbance. Where: } \\
\text { "ecological resilience is the amount of disturbance that a system can absorb before it } \\
\text { changes state. Ecological resilience is based on the demonstrated property of alternative } \\
\text { stable states in ecological systems. Engineering resilience implies only one stable state } \\
\text { (and global equilibrium)". Further: "a resilient ecosystem can withstand shocks and } \\
\text { rebuilds itself when necessary. Resilience in social systems has the added capacity of } \\
\text { humans to anticipate and plan for the future". Resilience is conferred in human and } \\
\text { ecological systems by adaptive capacity. }\end{array}$ & $\begin{array}{l}\text { The resistance and robustness of an integrated system } \\
\text { against surprises, which includes risk-based measures and } \\
\text { precautionary regulations; the capacity to buffer change, } \\
\text { learn and develop. }\end{array}$ \\
\hline Complexity & $\begin{array}{l}\text { From a biology perspective: "that understanding of how the parts of a biological } \\
\text { system - genes or molecules - interact is just as important as understanding the parts } \\
\text { themselves". From a natural systems perspective: "complex interactions of natural } \\
\text { systems that are not chaotic". Furthermore, the growing appreciation of the need to } \\
\text { work with affected stakeholders to understand the full range of aspects of any particular } \\
\text { system. }\end{array}$ & $\begin{array}{l}\text { Deals with the study of complex systems, i.e. is composed of } \\
\text { many interacting elements that interact in complex ways; } \\
\text { and the ability to model complex interaction structures with } \\
\text { few parameters. }\end{array}$ \\
\hline $\begin{array}{l}\text { Adaptive } \\
\text { management }\end{array}$ & \multirow{2}{*}{\multicolumn{2}{|c|}{$\begin{array}{l}\text { Or adaptive resource management (ARM) is an iterative process of optimal decision-making in the face of uncertainty, with an aim to reducing that } \\
\text { uncertainty over time via system monitoring. } \\
\text { "As applied to human social systems, the adaptive capacity is determined by: } \\
\text { - The ability of institutions and networks to learn, and store knowledge and experience. } \\
\text { - Creative flexibility in decision-making and problem solving. } \\
\text { - The existence of power structures that are responsive and consider the needs of all stakeholders. } \\
\text { Adaptive capacity is associated with } \mathrm{r} \text { and K selection strategies in ecology and with a movement from explosive positive feedback to sustainable } \\
\text { negative feedback loops in social systems and technologies". }\end{array}$}} \\
\hline Adaptive capacity & & \\
\hline
\end{tabular}

institutional and social sub-systems, also termed holons [8], are used interchangeably through a sub-learning cycle to [5]:

- Define a specific system, as a framework, in terms of technology-economic-social-ecological-institution interactions, including the boundaries of the system, and important resilience considerations; and

- Establish a hierarchy of controllable indicators that may be affected in terms of their respective importance to ensure the sustainability, as defined by the concepts of Table 1 , of the investigated technology-economic-social-ecological-institution system.

The outcome is an initial set of prioritised indicators for each of the technology, economic, social, ecological, and institutional sub-systems or holons according to the overall system sustainability, as perceived by the sustainability expertises (\#2 of Fig. 1). The technology holon analysts then re-evaluate, through a number of sub-cycles, the site-specific information to determine which indicators are, potentially, assessable for the specific technological system under investigation (\#3 of Fig. 1). Thereafter, the different stakeholders of the technology-economic-social-ecological-institution system are engaged to highlight the key aspects of the integrated system to prioritise the indicators and identify aspects of the overall system that may not have been included in the initial set of indicators (\#4 of Fig. 1 ). Further learning cycles $(2 \rightarrow 3 \rightarrow 4 \rightarrow 2$ ) are utilised to facilitate the transdisciplinarity prioritisation of the key set of indicators. Finally, and considering the market uptake of innovation [9], multiple technology-economic-social-ecologicalinstitution systems at regional, national and international levels may result in different sets of prioritised assessable indicators through a continuous learning process.

The main objective of the investigation summarised in this paper was to apply the introduced model on a rural mini-hybrid off-grid electrification system to determine the sustainability performance of such systems in the African context. Thereby policy makers may be informed as to the key aspects that drive the sustainability of mini-hybrid off-grid renewable energy systems.

\section{Application of the model on an implemented renewable energy technological system}

Supply of energy for basic needs is an assumption for sustainable development of the South African National Department of Minerals and Energy (DME) [10]. Household electrification and an energy grant of R $55(\sim € 5)$ per household per month are administered to local municipalities by the Department of Provincial and Local Government (DPLG). In rural areas up to $84 \%$ of households can qualify for this grant [11]. In 2003 the DME embarked on a renewable energy project in the OR Tambo municipality Lucingweni Village in the Eastern Cape Province, which was used to test the viability of renewable energy for locations not accessible to the national grid; the introduced model (of Section 1) was applied to the Lucingweni case study [3,5].

\subsection{Scope of the study}

The boundaries of the case study were set at the borders of Lucingweni Village with its four neighbouring villages and a nature reserve; the details of the case are described elsewhere $[3,12]$. The time period for the case study was from September 2004 to January 2007. The boundaries and key elements have been described for the following sub-systems [3]:

- Socio-political - the five villages and the region that is controlled by a traditional, cultural government system.

- Socio-ecological - the area used by the villagers of Lucingweni for their ecological services.

- Socio-economic - the same as the socio-political sub-system with the nature reserve and an associated tourist camp that is a source of employment, including the economic services that are provided as part of the non-traditional government system, i.e. a clinic and school, through the Eastern Cape Parks Board of the South African government.

- Technological - the area to which the power lines are extended. This is a subset of the Lucingweni village. 


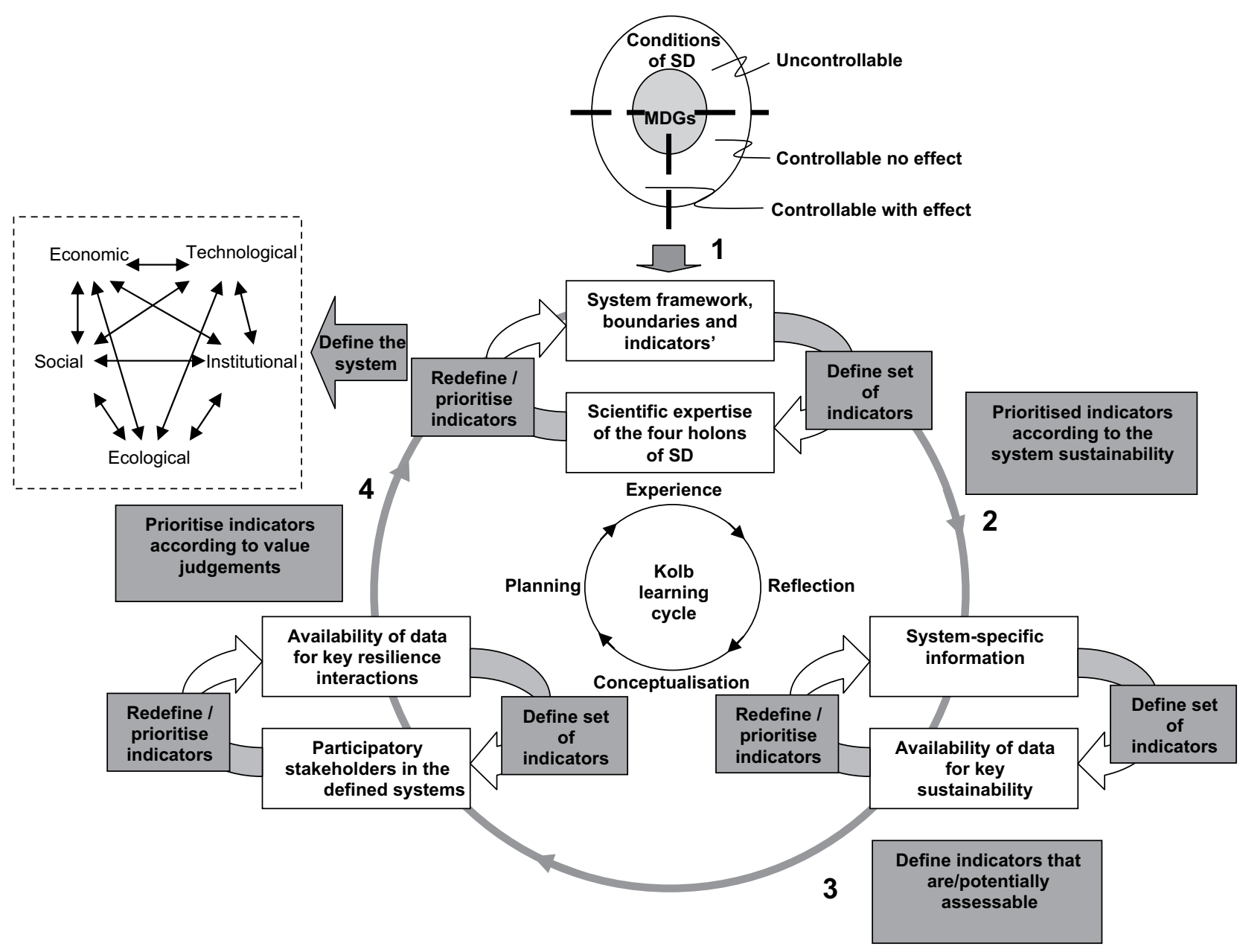

Fig. 1. Model to achieve prioritised assessable sustainable performance indicators for technological systems [5].

\subsection{Flows across boundaries}

Productive capacity in the Village is in agriculture. Trade and financial transactions across borders are therefore for production in the village and remittances from government grants, and migrant workers. Energy flows across the boundaries are for fossil liquid fuels for transport, cooking, lighting, and refrigeration; and biomass for heat and cooking.

\subsection{Sources and quantities of renewable energy}

The useful energy that can be provided by the six wind turbines (6 kW-peak) and 540 solar panels $(0.113 \mathrm{~kW}$-peak) of the minihybrid off-grid technological sub-system is determined from the available wind and sun at the coordinates (Latitude $31.825 \mathrm{~S}$ and Longitude $29.254 \mathrm{E}$ ). The strongest local wind is located on the edge of an escarpment, and polycrystalline Si collectors are located adjacent to the wind turbines (see Fig. 2). Table 2 shows the available wind and sun energy per day. This daily energy takes up on average an estimated $25 \%$ of the maximum capacity of the wind turbines, and $19 \%$ of the photo-voltaic cells.

\subsection{Electrical system conversion efficiencies}

The flow of energy through the electrical system is shown schematically in Fig. 3. The amount of useful energy that can be obtained at the household connections can be determined from the input energy from the turbine and the photo-voltaic and subtracting the energy losses in each of the components of the 220 AC $50 \mathrm{hz}$ distribution system. The energy losses of each component in the system are estimated in Table 3.

112 households were connected to the system. The useful energy from the $97 \mathrm{~kW}$ peak system that is available at the 112 household connections is about 125 watts continuous (see Table 4). This provides energy per household connection of just over $3 \mathrm{kWh}$ per month.

\section{Results: prioritised sustainability indicators for the system}

The assumptions of three main sustainability paradigms were used as the starting point for identification of the elements in each of the sub-systems (\#1 of Fig. 1). These were the United Nations Millennium Development Goals (MDGs) to which South Africa has subscribed; the World Commission on Environment and Development, i.e. the Brundtland Report, which has provided the first and only global consensus on conditions for sustainability [5]; and the Stern Review [13], which has provided the most widely accepted techno-economic model for mitigation against climate change. The measured and assessable indicators specified in these paradigms have been used as the initial elements (Fig. 4). Additional sustainability and sustainable development indicators were identified through the described learning model (\#2 of Fig. 1). Prioritisation was included in the model, and this distinguished between those elements which 




Fig. 2. The Lucingweni Village mini-hybrid off-grid system.

were deemed uncontrollable, and controllable with, and with no effect (see Fig. 4). Expert knowledge was obtained by way of review of initial sustainability mapping of the sub-systems with the University of Pretoria's Departments of Economics, Law and Governance, and Ecology; the Competency Areas of the South African Council for Scientific and Industrial Research (CSIR) in Energy Processing, Energy Infrastructure, and Resource Based Sustainable Development; the DME's Directorate of Renewable Energy; and the National Energy Regulator of South Africa (NERSA) in terms of project management (\#3 of Fig. 1). Interviews were conducted with the Local Municipality Manager and

Table 2

Projected average wind and sun energy, and capacity factors.

\begin{tabular}{llcl}
\hline Wind & Wind velocity & 6.32 & $\mathrm{~m} / \mathrm{s}$ (10 year average) \\
& Turbine Output & 9.00 & $\mathrm{~kW}$ \\
& Output/day & 147 & $\mathrm{kWh} /$ day \\
& Capacity factor & 25 & $\%$ - Output power/peak power \\
Sun & Solar radiance & 4.67 & $\mathrm{kWh} / \mathrm{m} 2 /$ day $(10$ year average) \\
& & 3.48 & $\mathrm{hrs}$ full sun/day \\
& Efficiency Si PV & 11 & $\%$ - Output power/input power \\
& Output/day & 190 & $\mathrm{kWh} /$ day \\
& Capacity factor & 19 & $\%$ - Output power/peak power \\
\hline
\end{tabular}

Council, the Ward Councillor, the Ward Council Committee, the traditional Head Man of Lucingweni Village, and the Headman's Committee (\#4 of Fig. 1). Technology inputs were supplied by the technology contractor, and its network of technology suppliers; the District Municipality; the national electricity utility (Eskom); and adjacent Eskom grid consumers (\#4 of Fig. 1).

The conditions for sustainability were prioritised through the engagement with holon expertise and other stakeholders of the system, as described in Section 1. The prioritised set of assessable indicators for the renewable energy system is given in Table 5; details of all the prioritised indicators are provided elsewhere $[3,5,9]$.

\section{Discussion: outcomes of the sustainability assessment}

The most important aspects were identified as the economic beneficiation from the technological intervention as expected by the community, and the community ownership of the technological system as expected by the lead implementing agency. From an economic and institutional perspective the community expected that they would receive a similar service, and performance, as provided by the national electricity grid. However, the capacity and 


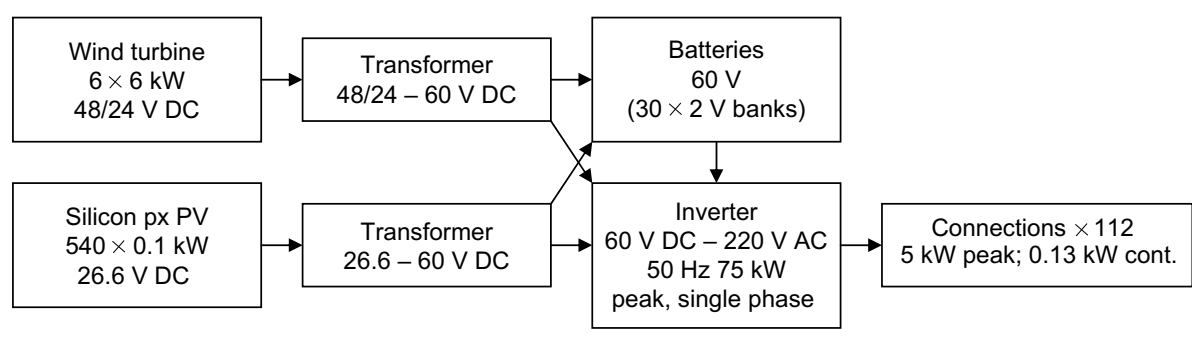

Fig. 3. Energy flows from generators to users.

Table 3

Conversion efficiency of distribution system components, storage, DC/AC conversion and AC distribution.

\begin{tabular}{lc}
\hline Transformer & $99 \%$ \\
Battery & $85 \%$ \\
Battery temperature derating & $97 \%$ \\
Inverter efficiency & $85 \%$ \\
Power conditioning & $99 \%$ \\
Line losses & $99 \%$ \\
Sum of energy losses & $32 \%$ \\
\hline
\end{tabular}

reliability of the technological system proved insufficient to meet these expectations.

\subsection{Demand versus production}

Observation from the site visit was that average demand exceeded average generation capacity of $3 \mathrm{kWh}$ per day per household connection.

\subsubsection{Energy charges and demand in the case study area}

A reason for the high demand for electricity in the region can be seen from the charges for energy in the adjacent areas. Electricity has the lowest charge by a factor of $2-3$. For this reason electricity is the energy carrier of choice for high energy services, i.e. cooking and refrigeration. The national electricity utility [14] advises that electricity demand doubles soon after installation when people want stoves and refrigerators. In the Lucingweni Village, household connections were provided with a 20 A trip switch, but behaviours resulted in many of the households bypassing this trip switch.

Municipalities are authorized to derive revenue from the sale of electricity. Municipal electricity charges are typically made up of a municipal levy of $\mathrm{R} 0.23 / \mathrm{kWh}$ plus the national utility's supply charge of R 0.16/kWh (see Table 6); 10 South African Rands (R) were equal to about 1 Euro $(€)$. The site visit found that electricity sales can be the single largest source of revenue for South African municipalities (see Table 7).

\subsubsection{Municipality subsidy from the DME}

As indicated in Section 2, the DME free basic alternative energy policy for off-grid support to indigent households is administered by DPLG. At the national utility's electricity charges in the vicinity, the off-grid support is equivalent to either 166 or $359 \mathrm{kWh}$ per household (Table 8), depending on the charge of the levy by the municipality. The indigent subsidy policy for urban households is $50 \mathrm{kWh}$ per household connection.

\subsubsection{Potential offsets for renewable energy projects}

Renewable energy projects attract carbon subsidies from South Africa and international institutions, but for potential project implementers, a determining barrier is often the administrative costs. In order for registration and auditing to be a small fraction of the total project costs, a minimum number of carbon credits are needed. In January 2007 typical incomes that might have been obtained were:

- Tradable Renewable Energy Certificates; R 0.12/kWh which has been reported by DME and this is equivalent to R $15000 / a$, i.e. less than $€ 1500$ per annum.

- A DME Renewable Energy Subsidy of $20 \%$ of the capital cost, i.e. $\mathrm{R} 1.04 / \mathrm{kWh}$ or less than $€ 15000$ per annum was available in early 2007.

- NERSA household connection subsidy; at about R 4500 per household this was equivalent to R $1.78 / \mathrm{kWh}$.

- EU Green House Gas emission trading scheme for 2007 ranged between R 0.04 and $\mathrm{R} 0.40 / \mathrm{kWh}$.

These incomes could provide a total of $\mathrm{R} 3.34 / \mathrm{kWh}$, but the administrative costs would be most cost effective if only the NERSA and DME renewable energy subsidies were claimed at the start of the project, i.e. $\mathrm{R} 2.82 / \mathrm{kWh}$.

\subsubsection{Electricity costs for off-grid municipal supply from wind} and solar power and the national grid coal power

The cost of electricity supply for the DME renewable energy village project using wind and sun was estimated from projections of energy outputs and the budget of the Lucingweni Village project.

Table 4

Net system power availability for the $97 \mathrm{~kW}$ DC system is $125 \mathrm{~W}$ AC per household.

\begin{tabular}{|c|c|c|c|c|c|c|c|c|}
\hline \multirow[t]{2}{*}{ Energy generators } & \multirow{2}{*}{$\begin{array}{l}\begin{array}{l}\text { Power } \\
\text { peak }\end{array} \\
\mathrm{kW} \mathrm{DC}\end{array}$} & \multirow{2}{*}{$\begin{array}{l}\text { Capacity } \\
\text { factor }^{\mathrm{a}} \\
\% \text { of kW DC Peak }\end{array}$} & \multirow{2}{*}{$\begin{array}{l}\text { Conversion } \\
\text { losses } \\
\% \mathrm{kWp}\end{array}$} & \multicolumn{2}{|l|}{$\begin{array}{l}\text { Usable power } \\
\text { in grid }^{\mathrm{b}}\end{array}$} & \multirow{2}{*}{$\begin{array}{l}\text { Usable power/ } \\
\text { Peak power } \\
\frac{\mathrm{kW}-\mathrm{AC} / \mathrm{kW}-\mathrm{DC}}{}\end{array}$} & \multicolumn{2}{|c|}{$\begin{array}{l}\text { Power per } \\
\text { household per day }\end{array}$} \\
\hline & & & & kWh AC/day & kW cont. & & kWh AC & $\mathrm{kW} A C$ \\
\hline Wind turbines & 36 & $25 \%$ & $32 \%$ & 146.9 & 6 & $17 \%$ & 1.311 & 0.055 \\
\hline Silicon photo-voltaic & 61 & $19 \%$ & $32 \%$ & 190.4 & 8 & $13 \%$ & 1.700 & 0.071 \\
\hline Total wind and solar & 97 & - & - & 337.3 & 14 & $15 \%$ & 3.012 & 0.125 \\
\hline
\end{tabular}

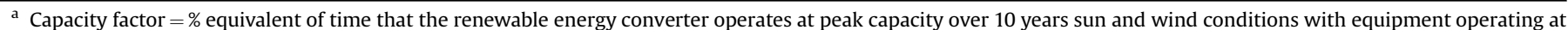
delivery specifications.

b Usable power estimate has a zero down time, i.e., batteries supply power during maintenance and the supply is greater than demand. 


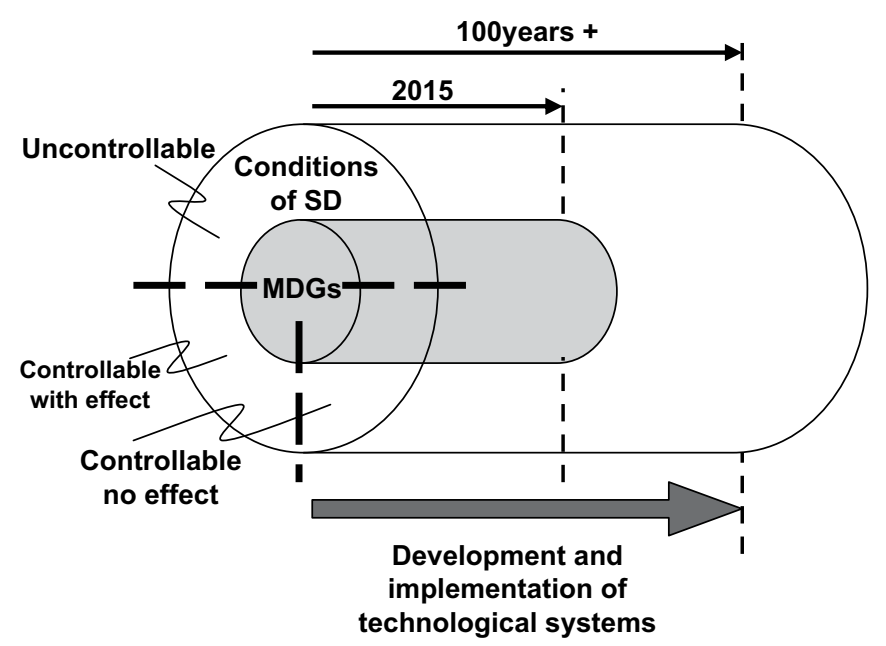

Fig. 4. Technological systems aim to contribute to short-term Millennium Development Goals (MDGs) as a subset of the long-term conditions of Sustainable Development (SD) [5].

In 2007 Rands, the total system cost was $\mathrm{R} 7.76 / \mathrm{kWh}$ for $119000 \mathrm{kWh} / \mathrm{a}$. The national utility cost for 2007 was $\mathrm{R} 0.16 / \mathrm{kWh}$, or approximately 50 times lower. Reasons for this are attributable to:
- Energy conversion losses between the source of electricity and the consumer are higher. About 30\% is lost by battery storage and DC to AC conversion (see Tables 3 and 4). In comparison the transmission losses in the national grid are expected to be up to $10 \%$.

- Capital costs for the battery storage make up $40 \%$ of the total costs. The pumped storage in the national grid is estimated at $1 \%$ of the capital cost.

- Capital costs of renewable electricity generators have low capacity factors, i.e. $25 \%$ and $19 \%$. These compare unfavourably with coal fired power stations that operate at $87 \%$ of maximum rated output.

- The national utility's capital costs are typically based on old and depreciated plant. New renewable energy generators have yet to be written off.

- Connection costs in rural areas can be subsidized by NERSA in a once-off payment and are therefore not included in the tariff of the national utility.

The DME subsidy system operating in 2007 provided for a onceoff subsidy of $20 \%$ [12]. This is equivalent to a grant of approximately $\mathrm{R} 1 / \mathrm{kWh}$. The inclusion of the DME and NERSA subsidies results in a Renewable Village Energy cost of about R 5/kWh. Therefore, the R 55 household energy grant from DME, provides for a maximum of $11 \mathrm{kWh} /$ month. It is reasonable to expect that the traditional leader and the Nyandeni Local Municipality, and the DME, would prefer

Table 5

Overall prioritised assessable sustainability indicators for the renewable energy technological systems [3,5,9].

\begin{tabular}{|c|c|c|c|c|c|c|}
\hline \multicolumn{3}{|c|}{ Indicator performance } & \multicolumn{2}{|c|}{$\begin{array}{l}\text { Changes due to } \\
\text { technological intervention }\end{array}$} & \multirow[t]{2}{*}{ Unit } & \multirow[t]{2}{*}{ Remark } \\
\hline Holon & Priority & Indicator & Designed for & Outcome after & & \\
\hline \multirow[t]{7}{*}{ Economic } & A & PPP & None & None & US\$/head/day & $\begin{array}{l}\text { Purchase Power Parity; international benchmark of ability } \\
\text { to meet basic needs with available resources. }\end{array}$ \\
\hline & A & Gini & None & None & \% Income lowest quartile & Gini (share of poorest quintile in national consumption). \\
\hline & A & Health & None & None & $\begin{array}{l}10 \text { years of adult working } \\
\text { life }\end{array}$ & $\begin{array}{l}\text { World Bank model of health of adults for productivity; } 0.4 \% \\
\text { productivity per } 10 \text { years life expectancy. }\end{array}$ \\
\hline & B & Education & Some & Some & $\begin{array}{l}\text { Years education working } \\
\text { adults }\end{array}$ & $\begin{array}{l}\text { World Bank model of education of adults for productivity; } 0.5 \% \\
\text { productivity per year at school. }\end{array}$ \\
\hline & $\mathrm{C}$ & Access to basic services & Some & Some & No units & Basic services are required for productivity. \\
\hline & B & $\begin{array}{l}\text { Positive return on energy } \\
\text { investments }\end{array}$ & Some & None & \% Return & $\begin{array}{l}\text { Energy output of system }>\text { factor of energy cost of inputs; to } \\
\text { ensure viable energy supplies. }\end{array}$ \\
\hline & $\mathrm{D}$ & Affordability energy & Yes & None & $\begin{array}{l}\% \text { Of income/disposable } \\
\text { resources }\end{array}$ & Energy cost for users is affordable. \\
\hline \multirow[t]{5}{*}{ Institutional } & A & $\begin{array}{l}\text { Allocation and control } \\
\text { of resources }\end{array}$ & Some & None & Contracts & $\begin{array}{l}\text { Allocation and control of resources. This is the indigent grant } \\
\text { system that is controlled by the responsible authority. }\end{array}$ \\
\hline & B & $\begin{array}{l}\text { Legal protection for } \\
\text { controls }\end{array}$ & None & None & Contracts/working services & $\begin{array}{l}\text { Legal protection to controls for resources. This is via contracts } \\
\text { between the suppliers and the users. }\end{array}$ \\
\hline & $\mathrm{C}$ & Access to credit & None & None & $\%$ Of assets & $\begin{array}{l}\text { This is via financial institutions that can use the assets as } \\
\text { collateral for loans. }\end{array}$ \\
\hline & $\mathrm{C}$ & Post Kyoto $\mathrm{CO}_{2}$ eq. targets & None & None & Tonnes $\mathrm{CO}_{2}$ eq. & $\begin{array}{l}\text { Post Kyoto targets for land use. Deforestation rates } \\
\text { should be reduced. }\end{array}$ \\
\hline & $\mathrm{D}$ & Access to basic resources & Yes & 3 months & National standards & $\begin{array}{l}\text { Access to basic resources is guaranteed by the constitution, } \\
\text { water and energy. Includes energy, clean water and sanitation. }\end{array}$ \\
\hline \multirow[t]{3}{*}{ Ecology } & A & $\begin{array}{l}\text { Biological community } \\
\text { diversity }\end{array}$ & None & Some & Acceptable trend & $\begin{array}{l}\text { Resilience of ecosystem is indicated by trends in indicator } \\
\text { populations for ecosystem type. }\end{array}$ \\
\hline & B & $\begin{array}{l}\text { Soil type maintenance } \\
\text { (fertility) }\end{array}$ & None & None & Acceptable trend & $\begin{array}{l}\text { Resilience of ecosystem is indicated by trends in soil } \\
\text { characteristics for soil type. }\end{array}$ \\
\hline & A & $\begin{array}{l}\text { Available natural energy } \\
\text { resource }\end{array}$ & Yes & Some & $\%$ Of need & $\begin{array}{l}\text { Natural resources must be available for conversion and the } \\
\text { excess should reflect the efficiency and the need for } \\
\text { stable supply. }\end{array}$ \\
\hline \multirow[t]{4}{*}{ Sociology } & A & Jobs (ability to get food) & None & Not direct & $\begin{array}{l}\text { Hours of saleable } \\
\text { production work }\end{array}$ & Best indicator of ability to self support for basic needs. \\
\hline & B & Nutrition & None & Not direct & Stunting of children & $\begin{array}{l}\text { Best indicator of food quality that affects productivity } \\
\text { and ability to learn. }\end{array}$ \\
\hline & B & Life expectancy & None & Not direct & Years & $\begin{array}{l}\text { Best overall measure of resilience of social systems is average } \\
\text { life expectancy. }\end{array}$ \\
\hline & $\mathrm{C}$ & Literacy & Yes & Yes & Standard literacy test & $\begin{array}{l}\text { Best overall indicator of ability of humans to improve } \\
\text { productivity. }\end{array}$ \\
\hline Technology & $\mathrm{E}$ & Increased productivity & None & None & $\%$ Increase in production & $\begin{array}{l}\text { Ability of energy system to assist production, e.g. electrical } \\
\text { energy for means of production. }\end{array}$ \\
\hline
\end{tabular}


Table 6

Energy charges in the OR Tambo District Municipality (March 2007).

\begin{tabular}{lcccl}
\hline Energy carrier & LPG & Diesel & Paraffin & OR Tambo DM rural electricity \\
\hline $\mathrm{MJ} / \mathrm{kg}$ & 48.55 & 38.1 & 37.00 & \\
$\mathrm{R} / \mathrm{kg}$ & 19.00 & 6.58 & 7.39 & \\
$\mathrm{R} / \mathrm{MJ}$ & 0.39 & 0.17 & 0.20 & 0.11 \\
$\mathrm{R} / \mathrm{kWh}$ & & & & 0.39 \\
\hline
\end{tabular}

10 South African Rands (R) were equal to approximately 1 Euro (€).

a quantity closer to the indigent allocation of $50 \mathrm{kWh}$ to national grid connections.

\subsection{Alternative technological solutions for sustainable development}

The DME needs a more economical electricity supply if the indigent grant subsidy scheme is to be used for renewable energy off-grid applications. Different alternative technologies options were subsequently considered.

\subsubsection{Village grid energy storage in lead-acid batteries or diesel?}

The DME renewable energy village has battery capacity for storage for up to $100 \mathrm{~h}$ of windless and overcast days, i.e. for approximately $1400 \mathrm{kWh}$. This storage can be provided by about 5001 of diesel. The cost of a $75 \mathrm{~kW}$ peak diesel generator was approximately R 200000 , or $€ 20000$, and included a fuel tank. In comparison, lead-acid battery bank capital cost was R 3000000 [12]. While the running costs of diesel were higher they were not high enough in January 2007 (R 5.6/1) to make diesel unaffordable ( $\mathrm{R} 2.85 / \mathrm{kWh}$ ) compared to renewable energy ( $\mathrm{R} 7.76 / \mathrm{kWh}$ ). This is still an order of magnitude more expensive than the national utility charge, but improves affordability of a stand alone rural village grid by a factor of 2.7 .

\subsubsection{Village grid storage or national grid storage?}

The national grid has a smaller differential between peak and average demand (see Table 9) and a lower portion of the supply from pump storage (248 MW and $0.9 \%$ of supply capacity) compared to the lead-acid batteries ( $1400 \mathrm{kWh}$ and $100 \%$ of the village supply) [12]. Connection to a national grid for renewable energy would have saved storage costs of R 3.15/kWh [12].

\subsubsection{Low cost extension of the national grid?}

Technological innovations from the national electrification programme have been attributed to user based standards, rather than supplier based standards [15]. These standards enable uniformity in procurement and national uptake of successful interventions, and shorter times on fault corrections during implementation. These innovations included prepaid meters and low cost grid extension; Single Wire Earth Return (SWER) technology replaced both three phase and single phase grid extension.

A national utility cost for a $5000 \mathrm{~kW}$ line extension of $13 \mathrm{~km}$ from the adjacent Mdumbi Village to Lucingweni Village, using a standard grid controller would have cost about R 40000 per $\mathrm{km}$ or about R 0.91/kWh [12]. Normal grid extensions required in rural areas are limited by bulk infrastructure capacity, but in the case of

Table 7

OR Tambo District Municipality income from electricity at a rural connection (March 2007).

\begin{tabular}{llll}
\hline Units & OR Tambo DM charge & ESKOM national average cost & ORTambo DM levy \\
\hline $\mathrm{R} / \mathrm{MJ}$ & 0.11 & 0.05 & 0.06 \\
$\mathrm{R} / \mathrm{kWh}$ & 0.39 & 0.16 & 0.23 \\
\hline
\end{tabular}

10 South African Rands (R) were equal to approximately 1 Euro $(€)$
Table 8

Estimated municipality monthly demand using the DME basic grant funding for 2007.

\begin{tabular}{|c|c|c|}
\hline \multirow{2}{*}{$\begin{array}{l}\text { Municipal charge system to DME } \\
\text { indigent grant }\end{array}$} & Cost $^{\mathrm{a}}$ for electricity & Demand $^{\mathrm{b}}$ from policy \\
\hline & $\mathrm{R} / \mathrm{kWh}$ & kWh AC \\
\hline Without levy & 0.13 & 359 \\
\hline With levy & 0.39 & 166 \\
\hline
\end{tabular}

a Cost includes VAT.

b Demand is based on a CPI $+1.5 \%$ escalation of the $\mathrm{R} 55$ grant per annum from 2003.

a small additional load ( $14 \mathrm{~kW})$ this is not a restriction. The extension would provide $50 \mathrm{kWh}$ per household within the DME grant. If this project was funded as a stand alone project the local municipality would, however, have to forgo approximately R 0.23 / kWh income on sales (see Table 7).

\subsubsection{Comparison with targets for South African low-carbon technologies}

South Africa's response to the high cost of carbon, climate mitigation, and energy shortages has so far been to commit to a long-term policy of power expansion based on renewable energy and nuclear power with high carbon tax [2]. The first response by the national utility is the largest project proposal in South African history, and the latest indications are that the cost for electricity will be in the range of $\mathrm{R} 1 / \mathrm{kWh}$ [16] assuming a growth of consumption at $6 \%$ per annum; there is high uncertainty in the cost, with estimates increasing rather than falling. This can be compared with the social cost of carbon, which the Stern Review [13] has estimated to be in the range US\$ 85-US\# 25 per tonne of $\mathrm{CO}_{2}$. This is equivalent to additional costs between $\mathrm{R} 0.7 / \mathrm{kWh}$ and $\mathrm{R} 2.6 / \mathrm{kWh}$, for the South African national grid that relies on coal with and average energy content of $21 \mathrm{MJ} / \mathrm{kg}$ and ash at $31 \%$ with power station efficiency of $34 \%$.

As this Lucingweni Village case study shows, renewable energy is more practical when connected to a large grid. For 2007 prices the village wind electricity is about $\mathrm{R} 1.70 \mathrm{R} / \mathrm{kWh}$ and solar PV about $\mathrm{R} 2.45 / \mathrm{kWh}$. These costs are the same range as the latest new costs of coal and nuclear electricity added to the lower social cost of carbon, i.e. $\mathrm{R} 2 / \mathrm{kWh}$. Renewable energy requires a carbon tax to bring into cost competitiveness with coal. A summary of the costs for three options in Table 10 shows that renewable energy is not affordable for local municipalities.

\subsection{Non-technical and institutional issues}

The disregard at the design stage for almost all of the nontechnical aspects has further resulted in an overall unsustainable system. The uncontrolled connections by the community resulted in system overload, disputes between all parties, and disconnections of power by the generator; the system stopped operating continually within one year of commissioning. Overall the management of the technological intervention did not improve the conditions of the social sub-system in the rural village or meet any of the performance aspects raised by the stakeholders. The result was the breakdown of trust between the traditional societal

Table 9

Peak and average demand for the village grid and the national grid.

\begin{tabular}{lll}
\hline Demand & Mini-grid $(\mathrm{KWh})$ & National grid $(\mathrm{kWh})$ \\
\hline Peak & 53 & 32000000 \\
Average & 14 & 22000000 \\
Ratio & 3.7 & 1.5 \\
\hline
\end{tabular}


Table 10

Comparison of options.

\begin{tabular}{llll}
\hline Option & & $\mathrm{R} / \mathrm{MJ}$ & $\mathrm{R} / \mathrm{kWh}$ \\
\hline National grid/Eskom & ESKOM national average cost & 0.05 & 0.16 \\
& OR Tambo DM levy & 0.06 & 0.23 \\
& OR Tambo DM charge & 0.11 & 0.39 \\
Village grid & Renewable energy village & 2.02 & 7.76 \\
National grid/Renewable & Wind and solar with NERSA and & 0.48 & 1.83 \\
& DME subsidies & & \\
\hline
\end{tabular}

structures and the formal government structures, and the technology developers. The case study therefore emphasizes that in the pre-feasibility and feasibility phase of the technology life cycle a holistic understanding of energy needs and other expectations is crucial. If an integrated system is addressed as a whole the overall resilience and adaptive capacity of all the sustainability aspects can be improved. Also, the system design needs to accentuate strategies for the technological intervention to ensure adaptive management of the integrated system in society.

The case study highlights the importance of the principles of sustainability science (see Table 1 ) to design and manage renewable energy technologies [9]:

- Transdisciplinarity. The different perspectives of experts and stakeholders on the aspects of sustainability are essential for the design stage. Thereby, technology designers can acquire a practical integrated understanding of the most important aspects and obtain agreement on the most important performance indicators for a type of technological intervention.

- Resilience. A key aspect to the sustainability of the integrated system is the trust between society and institutions, and technology developers and implementers. A breakdown of trust will result in society not accepting and adopting the technology intervention. Depending on the context, ecological and economic aspects may determine the resilience of the overall system to the technological intervention, e.g. the capacity of natural resources, and affordability.

- Complexity. Interactions between and within human and natural systems can result in misunderstanding and a mismatch between expectations and bio-physical and economic capacities. This complexity is likely to be poorly understood initially, and therefore deductive rather than inductive learning should direct technological design and intervention. Especially behavioural changes in the socio-economic, and the implications thereof for ecological systems, have high uncertainty.

- Adaptive management. Renewable energy for electricity generation is relatively new to remote areas of developing countries. The management of a technology during and after intervention requires technical skills and understanding of equipment performance and economic benefits that are not readily available in this traditional context. Traditional social structures that need to support the technological intervention must be engaged to deal with the adaptive responses to changes in social values and eco-services.

- Adaptive capacity. The ability of the stakeholders to agree to experiment with alternatives to mitigate problems with sustainability aspects highlights the potential ability of the social system to learn and adapt to a technological intervention within the carrying capacity of the ecological systems and the technological capacity of the society over time. Renewable energy interventions should therefore provide flexibility for stakeholders to adapt to sustainability aspects within the constraints of the applicable social and institutional systems.

\subsection{Implications for policy-making to promote renewable energy technologies for off-grid applications}

The literature frequently makes recommendations to governments about their responsibilities and the policies they should implement for long-term sustainable development [17]. However, because social-ecological systems are self-organizing their evolution rarely follows the paths intended by governments [18] Governments are not free to invest or establish institutions at will, but must take account of the political influence of all stakeholders to promote sustainable technology-economic-social-ecologicalinstitution systems. The capacity of such systems to self-organize is the foundation of their resilience. Rebuilding this capacity at times requires access to external resources. Excessive subsidization can, however, reduce capacity. Cross-scale subsidization should end when self-organization becomes apparent, because cross-scale subsidization can increase the vulnerability of the broader system. A long-term perspective is essential, i.e. cross-scale relationships should in the long-term be mutually sustaining, neither exploitative from above nor parasitic from below [18]. Therein lays the challenge for policy-making related to the promotion of sustainable and adaptable renewable energy technologies in social-ecological systems, especially in remote areas.

\section{Conclusions and recommendations}

The investigation summarised in this paper set out to assess the sustainability of renewable energy technologies for off-grid applications, by applying an introduced learning model. The investigation focused on a rural village in the Eastern Cape Province of South Africa where a renewable energy system was implemented.

The complex interactions between the technological, economic, social, ecological, and institutional sub-system were demonstrated through the case study. The vulnerability of the overall system to issues such as trust and ownership was highlighted. Such issues emphasize that transdisciplinarity understanding is required by renewable energy technology designers to reduce uncertainty and improve the sustainability of technological interventions. Apart from technical aspects a holistic understanding of energy needs and implications, where a technology is to be introduced, is essential. The understating of implications or changes in the integrated system over time, in turn, could identify adaptive strategies for the management of renewable energy technologies. The learning capacity of cultures in specific contexts, especially, is vital for the planning and decision-making of renewable energy systems. With such increased understanding it is envisaged that the sustainability performances of renewable energy technological interventions may be improved during the design stages, i.e. during the pre-feasibility and feasibility phases, and in the uptake stages, i.e. the transfer and adoption phases, of the technology life cycle.

The renewable energy system of the case study was found to be unsustainable. In essence renewable energy for off-grid rural electrification does not meet the South African Millennium Development Goals commitments for poverty reduction, because the return in productivity is uncertain and the cost is too high for the institutional support from the National Department of Minerals and Energy (DME). The failure of the integrated systems was further found to be attributed to:

- The complexity of the social-institutional sub-system, which resulted in uncertainty for project planners and system designers; and 
- The lack of resilience of the technological system to demands from the social, economic and institutional sub-systems.

If renewable energy in remote off-grid areas is to be linked to sustainable development goals then national grid connection is required.

\subsection{Recommendations for the management of renewable energy technologies}

For technology management in general, further research is therefore required to understand the complexity of social-institutional (and ecological) systems as they relate to technological systems to reduce the uncertainty for technology designers and decision-makers. For example, the means to measure and track trust and ownership within an integrated system. The development of resilience parameters and associated factors for the design of technological systems can then be undertaken. It is envisaged that such parameters and factors can be used for the development of technology assessment methods and metrics, as they are used in technology management practices. To this end, the modification of the widely used Technology Balance Sheet, Income Statement and Space Map analytical techniques are currently being investigated, with specific emphasis on the initial research and development phases of technology management [4].

\section{Acknowledgements}

The researchers would like to thank all the stakeholders that participated in the study and in particular the National Energy Regulator and Department of Minerals and Energy of South Africa, the faculty of the University of Pretoria as sustainability aspect expertise, the Ndayeni Municipality in the OR Tambo district of the Eastern Cape Province, the councillor and committee of ward 20 of the Municipality, the headman of the Lucingweni Village, and the households of Lucingweni Village that were interviewed. The authors further acknowledge the South African Council for Scientific and Industrial Research (CSIR) that made available the funding to undertake the case study.

\section{References}

[1] South African Department of Health. Millennium development goals country report, http://www.doh.gov.za; 2005 [online].

[2] Scenario Building Team. Long term mitigation scenarios: scenario document. Pretoria: Department of Environmental Affairs and Tourism, http://www.erc. uct.ac.za/Research/LTMS/LTMS-intro.htm; 2007 [online].

[3] Rogers DEC, Brent AC, Hietkamp S, Vena N, Kruger L. Performance measurement of renewable energy technology using sustainability science: case study Lucingweni mini-grid. Pretoria: Council for Scientific and Industrial Research; 2007. Project no. HTP011P.

[4] Brent AC, Pretorius MW. Sustainable development: a conceptual framework for the technology management field of knowledge and a departure for further research. South African Journal of Industrial Engineering 2008;19(1):31-52.

[5] Brent AC, Rogers DEC. Prioritising assessable sustainability performance indicators to manage renewable energy technologies in remote areas of Africa. In: Proceedings of the 10th World Renewable Energy Congress (WRECX). Glasgow, Scotland; 2008.

[6] Bertalanffy LV. General system theory: foundations, development, applications. New York: George Braziller; 1968.

[7] Kolb DA. Experiential learning: experience as the source of learning and development. Eaglewood Cliffs, NJ: Prentice Hall; 1984.

[8] Warren WA. Hierarchy theory in sociology, ecology, and resource management: a conceptual model for natural resource or environmental sociology and socioecological systems. Society and Natural Resources 2005;18(5): 447-66.

[9] Brent AC, Rogers DEC. Sustainability science and technology management. The case of renewable energy technologies. In: Annual international sustainable development research conference (AISDRC). Delhi, India; 2008.

[10] South African Department of Minerals and Energy (DME). Free basic alternative energy policy: households energy support programme, http://www.dme. gov.za; 2003 [online].

[11] South African Municipal Demarcation Board. Municipal profiles, www. demarcation.org.za; 2006 [online].

[12] Rogers DEC, Brent AC. Renewable rural electrification: prediction of sustainability in South Africa. In: CSIR outcomes conference Pretoria, South Africa; 2008.

[13] Stern N. Review on the economics of climate change. Office of the Prime Minister, United Kingdom; 2006.

[14] Eskom. Rural electrification connection costs, private communication. Pretoria; 2007.

[15] Bekker B, Eberhard A, Gaunt T, Marquard A. South Africa's rapid electrification programme: policy, institutional, planning, financing and technical innovations. Energy Policy 2008;36:3125-37.

[16] Eberhard A. Electricity pricing. Business Day October 2008.

[17] Winkler $\mathrm{H}$, editor. Energy policies for sustainable development in South Africa: options for the future. Cape Town: Energy Research Centre; 2006.

[18] Abel N, Cumming DHM, Anderies JM. Collapse and reorganization in socialecological systems: questions, some ideas, and policy implications. Ecology and Society 2006;11:1-17. 